NEWS

\title{
Stem cells from testes: could it work?
}

On Friday 24 March, researchers at the Georg August University of Göttingen in Germany announced they had found a source of reprogrammable cells in the testes of adult mice. By Sunday morning, more than ten companies had e-mailed senior team member Gerd Hasenfuss about collaborating on future work.

Hasenfuss, a cardiologist, admits that much work must be done before the discovery could lead to any applications in humans. But the finding drew attention immediately: it promises, at least for men, a simple and uncontroversial method for harvesting therapeutic stem cells. Two other research groups have made similar claims in the past, and a patent showdown among the three is looming.

As Hasenfuss's team reports in Nature, the reprogrammable cells come from spermproducing stem cells in mice (K. Guan et al. Nature doi:10.1038/nature 04697; 2006). It is not clear whether the cells in the testes have the ability to produce all other kinds of bodily cells, as embryonic stem cells can. But after the team extracted, cultured and multiplied the cells 700 -fold, they converted to an embryolike state in 4 out of 15 cases. When injected into early embryos, the converted cells helped build various organs of the resulting mouse. And, in vitro, the converted cells turned into several different types of cell, including heart, brain and skin cells.

Hoping to move the work into humans, the team has already received tissue samples from testicular-cancer patients. Hasenfuss thinks that, eventually, a simple biopsy could extract the necessary cells. Such cells would be a genetic

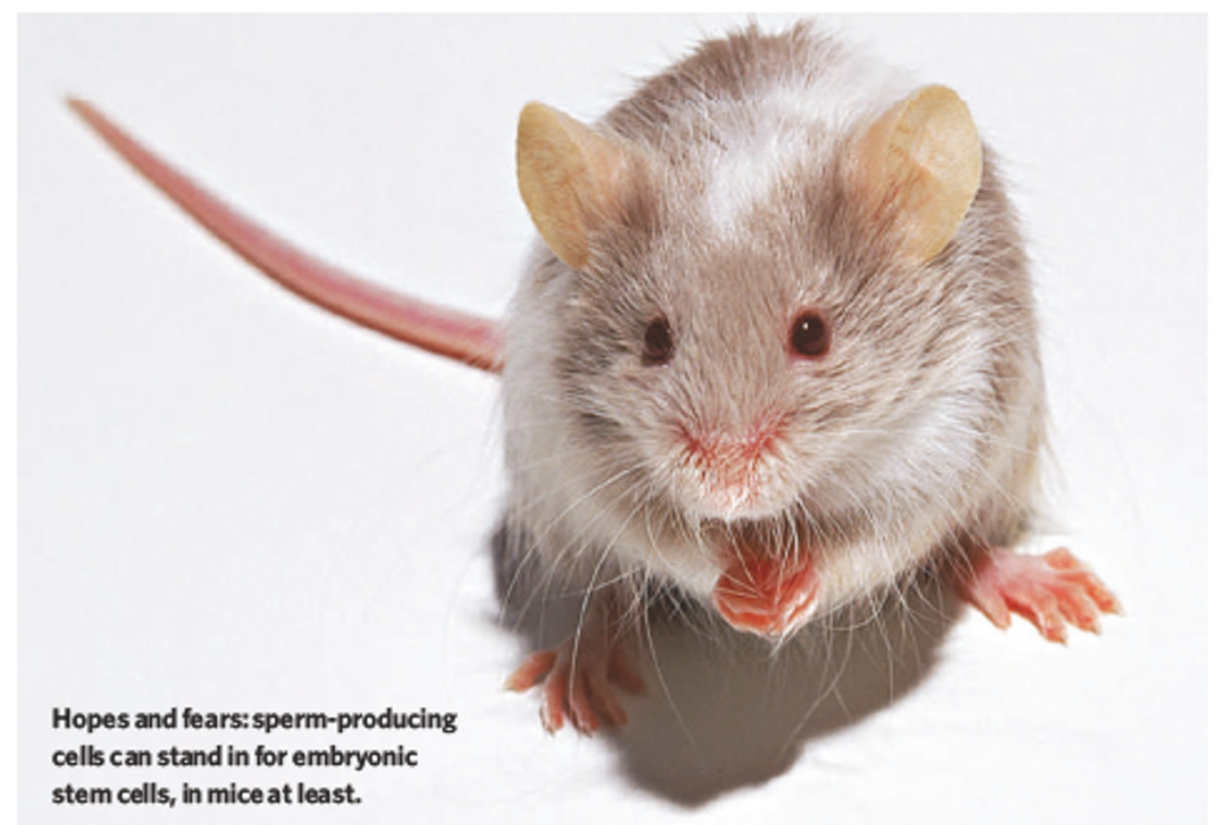

match with the patient, which makes them less likely to be rejected if used in therapy.

But Hasenfuss's work has its sceptics, including Takashi Shinohara, a mouse germ-cell expert at Japan's Kyoto University. Shinohara's group was the first to isolate reprogrammable cells from mouse testes, but it used two-day-old pups (M. Kanatsu-Shinohara et al. Cell 119, 1001-1012; 2004). His experience differs from that of the Göttingen researchers in some ways - for example, they report that stem cells injected into embryos are able to integrate into various tissues. "Perhaps they have some dif- ferent kind," he says, "but I don't think that type of cell exists."

Shinohara also points out that many researchers have tried doing similar experiments, with more sophisticated culture media, without the same results. "IIt's too good to be true," he says. Kaomei Guan, of the Göttingen team, counters that simplicity may be the key. Applying a complicated mix of certain growth factors in a lab dish for a long period of time, he says, can cause other cells to take over and the sperm stem cells to die.

A third, US-based group has already claimed

\section{Space scientists get double reprieve}

\section{WASHINGTON DC}

NASA reversed two decisions in one day on 27 March, reinstating the Dawn asteroid mission cancelled earlier this month and restoring some funds cut from astrobiology research. Both announcements have left scientists happy but also puzzled by a seemingly erratic decisionmaking process at the space agency, where managers are struggling to pay for an ambitious slate of science missions with a shrinking budget.

The US\$446-million Dawn mission is expected to launch in July 2007 to study the asteroids Vesta and Ceres. The mission had been scheduled to launch this June, but last autumn, NASA stopped work on the project, owing to technical problems and costoverruns.

Although an independent assessment team reported in January that there were no technical barriers to launch, NASA associate administratorMary Cleavecancelled the missionon 2 March. Her decision angered space scientists inthe
United States and in Germany, which is contributing funds and expertise to the mission. CharlesElachi, director of the Jet Propulsion Laboratory in

Pasadena, California, where Dawn is managed, asked NASA headquarters for a review. Ateam headed by associate administrator Rex Geveden decided on 23March that the technical and cost issues were sufficiently in hand to permit launch.

Scientists attending an astrobiology meeting from 26 to 30 March in Washington DC also heard of a reprieve, albeit a partial one. Carl Pilcher, NASA's senior scientist for astrobiology, had informed the community just last week that projected budget cuts of $50 \%$ meant that any grant proposals received in 2005 would beunlikely to be funded. Healso said there would be nosolicitation forproposals this year. At the Washingtonmeeting, Pilcher said NASA headquarters has decided to restore enough money to award at leasthalf the expected number of grants from 2005. Most 
some success in related experiments with human cells. Francisco Silva is vice-president of research at PrimeGen Biotech, based in Irvine, California. He says that, working with samples from 22 testes, the company "has successfully therapeutically reprogrammed human germ cells and differentiated them to multiple cell types in vitro". Silva has presented the data at scientific meetings, and says he plans to submit results for publication soon. But Shinohara is again sceptical.

Hasenfuss, Shinohara and PrimeGen all say they have filed for international patents on their technologies. Some legal squabbles are likely. Hasenfuss, for example, claims work in adult mice is different from that in neonatal mice. Shinohara says the two experiments are essentially the same.

Whether any of the mouse-based claims would cover humans is not clear. Even if a patent office grants a patent, it may be invalidated by the courts, says Lynn Pasahow, an intellectual-property attorney with Fenwick \& West in Mountain View, California (see 'US to rule on research patent'). "It may be difficult to know the scope of the valid claims," he says.

In any case, researchers still have to show that the cells can be derived, grown and manipulated just like those from the alternative source, cloned embryos. In theory, the reprogrammable testes cells could circumvent the ethical difficulties of stemcell work that involves destroying human embryos. "This could put the embryonic stem-cell people out of business," says Peter Donovan, a stem-cell expert at the University ofCalifornia, Irvine. "But it remains to be seen whether they work in humans." David Cyranoski

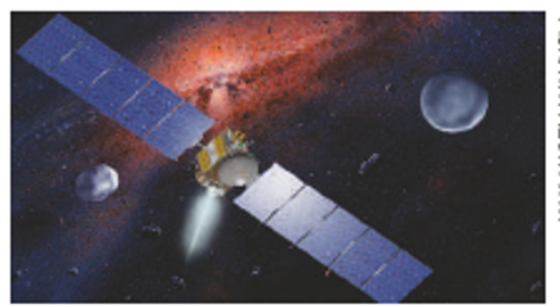

NASA's Dawn asteroidmission has been revived.

astrobiologists at the meeting applauded the news, but vowed to keep lobbying for more money. "We can see this as the beginning of a negotiation," says Baruch Blumberg, a Nobel laureate and former director of the NASA Astrobiology Institute.

Tomy Reichhardt

\section{US to rule on research patent}

\section{WASHINGTON DC}

It is a case that questions the very nature of what can be patented. Before the US Supreme Court adjourns at the end of June, it may decide whether a patent based on a biological relationship between two substances can be issued. A verdict could have implications for many other US and worldwide patents.

"The United States is often an incubator for these issues," says Francis Gurry, deputy director-general of the World Intellectual Property Organization in Geneva, Switzerland. "The world is watching with a great deal of interest."

A natural phenomenon or a law of nature generally cannot be patented, but a process that takes advantage of that phenomenon or law can be. Lawyers have been battling over this rule in biotechnology cases since at least 1980 , when the Supreme Court ruled that a newly discovered microbe capable of digesting petrol could be patented. That case opened the door for the biotechnology industry and ushered in patents for antibodies, microorganisms and cells.

Some feel that it is now too easy to patent natural phenomena. "There might be some individuals who would like to close that door," says Nick Godici, a former US Patent and Trademark Office commissioner .

The latest case Laboratory Corporation of America Holdings (LabCorp) against Metabolite Laboratories deals with the field of biomedical diagnostics. It stems from a patentinfringement case over

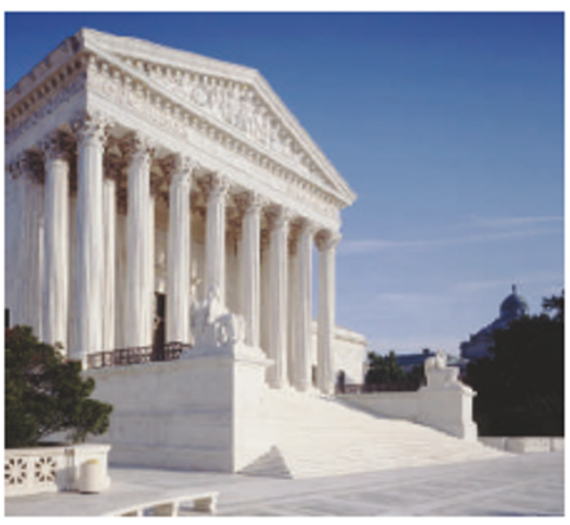

Thought police: the Supreme Courtis reviewing a case that could "wreak havoc on the patent world".

a method for diagnosing vitamin B deficiencies. In 1990 , Metabolite patented a diagnostic test, based on an assay that measures blood levels of homocysteine, an amino acid. High levels of homocysteine are correlated with low levels of vitamin $B_{12}$. Physicians often order such tests because high homocysteine levels are also correlated with increased health risks such as heart attacks, stroke and birth defects.

Metabolite licensed the test to LabCorp, a clinical testing company. LabCorp stopped using it in 1998 and replaced it with a similar test developed by another company. When LabCorp stopped paying royalties, Metabolite sued for patent infringement. LabCorp lost, was ordered to pay $\$ 7.8$ million, and lost again on appeal.

In the case heard by the Supreme Court on 21 March, LabCorp argued that Metabolite had patented a law of nature by asserting ownership of the relationship between homocysteine levels and vitamin $B_{12}$. Under these circumstances, LabCorp said, physicians infringe the patent simply by thinking about the relationship when studying test results.
Miguel Estrada, an attorney for Metabolite, told the court that the natural relationship is integral to the diagnostic step. Addressing the broader issue, he argued, could "wreak havoc on the patent world".

A corresponding European patent does not daim to cover the relationship between levels of homocysteine and vitamin $B_{12}$, and is not currently being challenged, says Siobhan Yeats, a biotechnology director at the European Patent Office in Munich, Germany.

The Supreme Court could now come to a verdict, pass the case back to thelower courts, or dismiss it altogether. One complication is that the biological-relationship argument was not addressed in the lower courts.

And although no one can predict which way the vote will go, at least one justice indicated his thoughts during the hearing. Justice Stephen Breyer hinted that patenting a scientific phenomenon might limit researchers' motivations to search for new cures. "If you don't provide them with an incentive," he said, "they may think of less." Jacqueline Ruttimann 